\title{
Biometrical analysis and thallus morphology characteristics of Placopsis antarctica from King George Island, Antarctica
}

\author{
Short Communication
}

\author{
Johanna Weiss $^{1}$, Alla Orekhova ${ }^{2 *}$ \\ ${ }^{1}$ University of Tuebingen, Faculty of Science, Geschwister-Scholl-Platz, 72074 Tübingen, \\ Germany \\ ${ }^{2}$ Laboratory of Photosynthetic Processes, Experimental Plant Biology Section, Depart- \\ ment of Experimental Biology, Faculty of Science, Masaryk University, Kamenice 5, \\ 62500 Brno, Czech Republic
}

\begin{abstract}
Placopsis antarctica is an ornithocoprophilous lichen that has been for a long time confused with $P$. contortuplicata I. M. Lamb. In our study, we focused on morphological characteristics of $P$. antarctica thalli. We report biometrical data on dominant morphological structures of $P$. antarctica thallus: cephalodia, marginal lobes, sorediate pits and soralia. Thalli of $P$. antarctica were collected at the King George Island, Antarctica and analyzed in a laboratory using a digital microscopy approach. Central cephalodium was found rather elliptic then round-shaped. Mean length/width was found 2.424/1.720 mm. Marginal lobes were found wider at the apex $(1.415 \mathrm{~mm})$ than basal part $(0.495 \mathrm{~mm})$. Side cephalodia were smaller, their mean length/width was found $1.034 / 0.610 \mathrm{~mm}$.
\end{abstract}

Key words: cephalodium, morphometry, Nostoc, algae symbiont, microrelief

DOI: $10.5817 / \mathrm{CPR} 2020-2-13$

\section{Introduction}

The lichen genus Placopsis consists of more than 60 species with distinct lobes that form a characteristic radial pattern from central cephalodium to thallus margin (Schmitt et al. 2003, Schneider et al. 2016). Cephalodium is a structure that possess colonies of cyanobacteria as sec- ondary photobionts, while marginal parts formed by lobes have an alga as primary photobiont. The cyanobacterial colonies are capable of both carbon and nitrogen fixation (Rai 1990). Nitrogen fixation is an important feature since fixed nitrogen is beneficial not only for the cyanobacteria, but

Received April 7, 2020, accepted October 8, 2020.

*Corresponding author: A. Orekhova <a.orechova@seznam.cz>

Acknowledgements: The authors are thankful for the funding that enabled collections of the samples from the field (INACH RT2716 Ecophysiology of Antarctic and Atacama lichens, CzechPolar-II LM2015078)) and provided infrastructure for the lichen thalli measurements and data processing (ECOPOLARIS: CZ.02.1.01/0.0/0.0/16_013/0001708)). The authors would like to express their thanks M. Barták for his help in data analysis, and J. Weiss for her help in morphological data gathering by digital optical microscopy. 
also for the other two partners, i.e. heterotrophic fungus and autotrophic algal photobiont. Raggio et al. (2012) suggested that increased intrathalline nitrogen content caused by cyanobacterial nitrogen fixation in cephalodium, may increase the photosynthetic rate of a lichen. Rai et al. (2000) reports that the frequency of heterocysts (cells specialized exclusively for the nitrogen fixation) is higher in cephalodia than when cyanobacteria are primary photobionts in lichen symbiosis.

For Placopsis sp., Nostoc commune is reported as dominant cyanopartner. However, thallus may include additional cyanobiont genera, such as Scytonema or Stigonema (Lamb 1947). Lichens of genus Placopsis are, therefore, nitrogen-fixing and considered main contributors of nitrogen in nutrient limited habitats. It is assumed that there is a link between nitrogen fixing cephalodia with a cyanobacterium and carbon fixation through more nitrogen being available for constructing photosynthetic machinery in algal part of the lichen. The link between nitrogen and carbon fixation is, however, still poorly understood (de los Ríos et al. 2011). Recently, the algal partners in Placopsis sp. from South Shetlands were described and identified as Stichococcus antarcticus (Beck et al. 2019). Moreover, the genus Stichococcus is being taxonomically investigated and revised (Pröschold and Darienko 2020). Application of chlorophyll fluorescence techniques showed that the cephalodia in Placopsis contortuplicata after wetting with water had low but substantial electron transport through PSII (Schroeter 1994, Casanova-
Katny et al. 2019a, b).

For Antarctica, four species of Placopsis have been reported: $P$. antarctica, $P$. contortuplicata, $P$. bicolor, and $P$. pycnotheca (compiled in Øvstedal and Lewis Smith 2011). Placopsis sp. are early successional pioneers in habitats where little else has colonized a rock/soil surface before. However, thanks to nitrogen fixation by cyanobiont in cephalodia, Placopsis sp. is considered fast growing species (Sancho et al. 2011) since it is scarcely limited by low nitrogen contents. Recently, the photosynthetic response of Placopsis sp. to increased air temperature has been investigated by $\mathrm{CO}_{2}$ exchange method (Colesie et al. 2018). For $P$. contortuplicata, high rates of net photosynthesis per Chl $a$ unit are reported (Palmquist et al. 2002).

For subantarctic regions and Antarctica, Placopsis sp. is reported mainly from Southern Chile (e.g. Raggio et al. 2012). In maritime Antarctica Placopsis sp. is reported for South Georgia, South Orkneys, and South Shetlends (King George Island in particular) - Australian Antarctic data Centre [1], Wirtz et al. (2003), Kim et al. (2006). The lichen genus Placopsis is a common component of high-rainfall, temperate biomes in southern South America with 18 species currently known from the region (Galloway 2002, 2010, 2013).

The aim of our study was to evaluate basic biometrical parameters for Placopsis antarctica. Our attention was payed mainly to dominant morphological structures forming a thallus: cephalodia, marginal lobes, sorediate pits and soralia.

\section{Material and Methods}

\section{Lichen collection and handling}

Thalli of Placopsis antarctica were collected from several particular localities at King George Island, Antarctica (La Cruz

mesa, Ardley peninsula and Collins bay) during the Chilean expedition in January 2019. The collections were done by two 
expedition members (A. Casanova-Katny and M. Barták) who monitored in situ responses of $P$. antarctica to manipulated warming by OTCs (Casanova-Katny and

\section{Description of the species}

$P$. antarctica was described in detail by Galloway et al. (2005) in the study reporting the species for the first time. Here we overview the most important characteristics from his study. $P$. antarctica thallus is closely orbicular and sometimes spreading in irregular patches. It has $1-3(-6) \mathrm{cm}$ in diameter, margins neatly plicate, entire, flabellate, swollen to somewhat flattened in parts, without a marginal prothallus. Lobes are convex, typically $0.5-1.0 \mathrm{~mm}$ diameter. They expand to $2.5 \mathrm{~mm}$ at apices. They are contiguous to somewhat overlapping, parallel, radiating from centre to periphery, separated by narrow to deeply gaping cracks, $0.5-1.2 \mathrm{~cm}$ long, then becoming areolate cracked centrally, areolae angular, 1-3 mm diam., separated by deep, gaping cracks, surface of areolae comprising crowded, and often eroded dactyls.

The upper surface is creamish, dullwhite, sometimes ivory to pale pinkish or greyish, with patches of glistening, crystalline, white pruina, suffused olive-brown at margins. Smooth to minutely pitted or irregular, dactyls are present. Dactyls are laminal, subglobose to globose, 0.2-1.0 $\mathrm{mm}$ diameter, $0.2-0.5 \mathrm{~mm}$ tall, solitary, to densely clustered. Hollow, apices are verrucose-areolate to erose, disintegrating into

\section{Results and Discussion}

Morphological characteristics are documented by the photographs (Fig. 1 to 16). The marginal lobes were found divided at the ends, and typically wider at the apical
Barták 2019a, b). Thalli were dried under natural (field conditions), then transferred to the laboratory where subjected to the optical microscopy study.

coarse, granular, white soredia, or abrading and leaving excavate, white, sorediate pits.

The photobiont in white part of the thallus is a green coccoid alga, cells of which are globose, 8-10 m diam. Cephalodia are submarginal to central, scattered, orbicular 2-8(-15) mm diam., sessile, spreading over thallus, globose at first, soon becoming conglomerate-convolute, to plicateridged, and breaking apart into island-likestructures separated by deep cracks when mature. Cephalodium colour is bluish purple, translucent when wet. The colour turns to pale pinkish brown to fawn when dry. Symbiotic cyanobiontis reported Scytonema sp.

Physiological characteristics, as well as biochemical features of $P$. antarctica are rather unknown. However, Strzalka et al. (2011) report that $\alpha$-tocopherol is present in high quantities in similar species Placopsis contortuplicata $(40.4 \mathrm{mg} / \mathrm{g}$ DW). The species do possess $\gamma$-tocopherol as well. The same authors reported xanthophyll-cycle pigments as well as neoxanthin and lutein. It is likely that the compounds are present also in $P$. antarctica. Confirmation of this is, however, matter of follow-up studies on P. antarctica.

part than at the lobe's base. They tended to be wider at the terminal then basal side by the factor of 2.86 (see Fig. 17). 


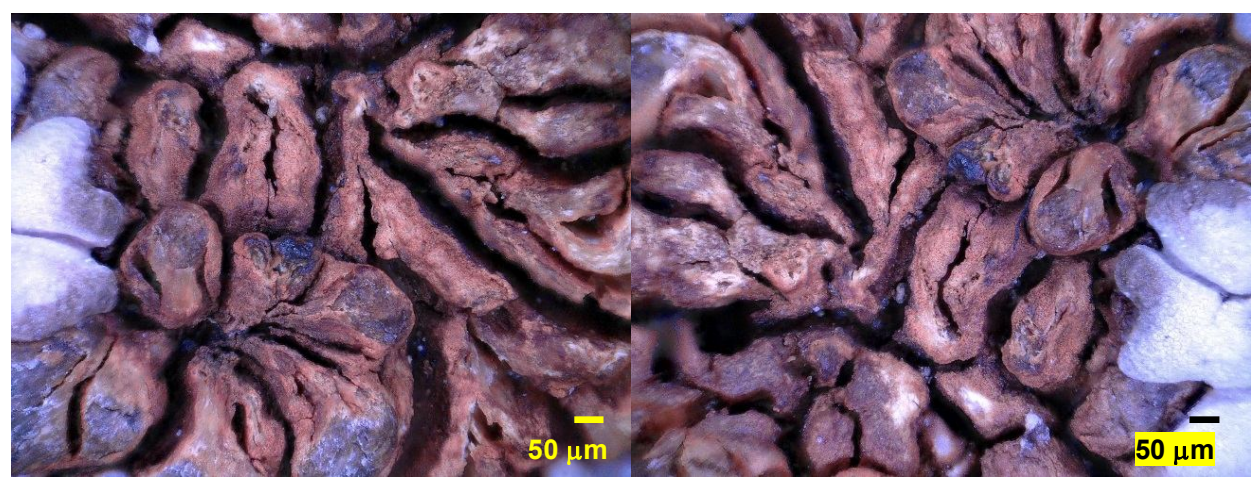

Fig. 1. Central part of dry cephalodium (see deep cracks).

Fig. 2. Central part of dry cephalodium.

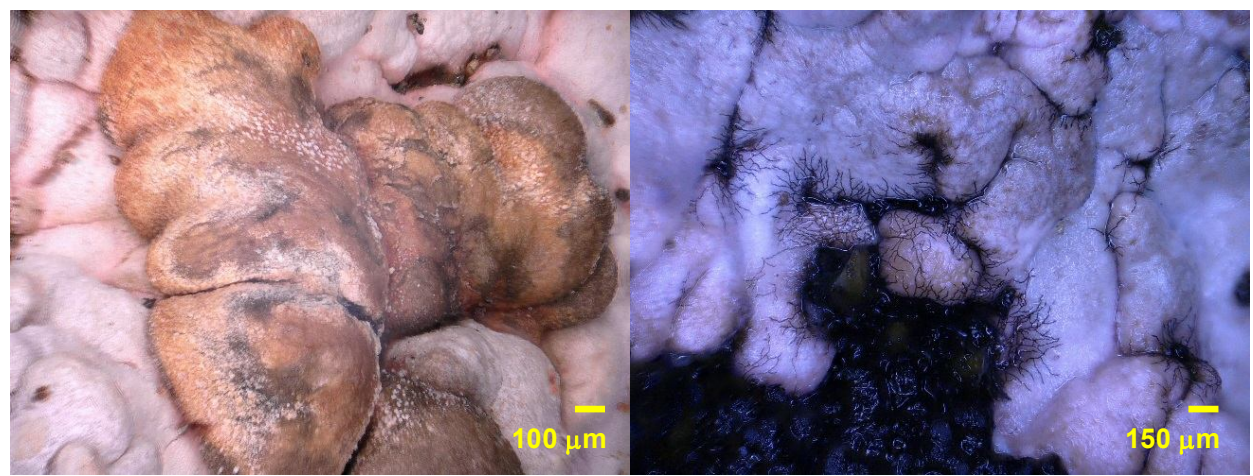

Fig. 3. Small cephalodium.

Fig. 4. Fungi inviding marginal part of thallus.

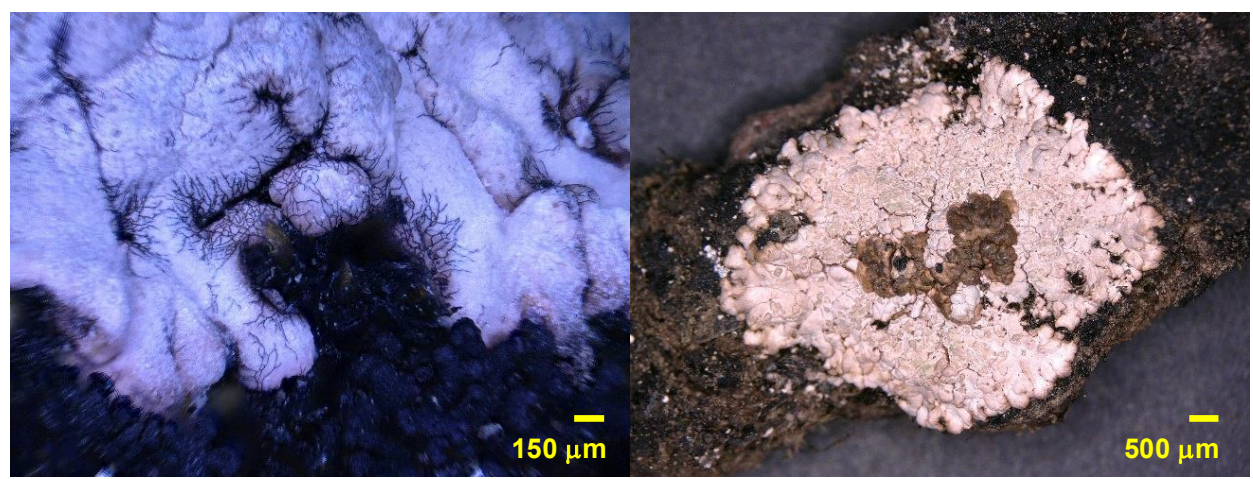

Fig. 5. Fungi inviding marginal part of thallus. Fig. 6. Overall view on $P$. antarctica. 


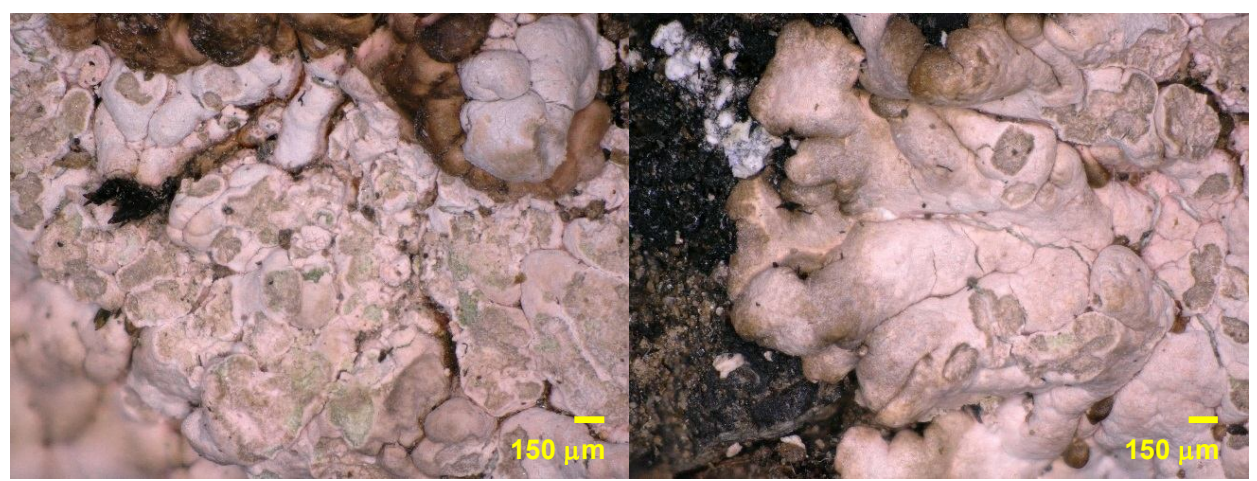

Fig. 7. Numerous sorediate pits.

Fig. 8. Sorediate pits.

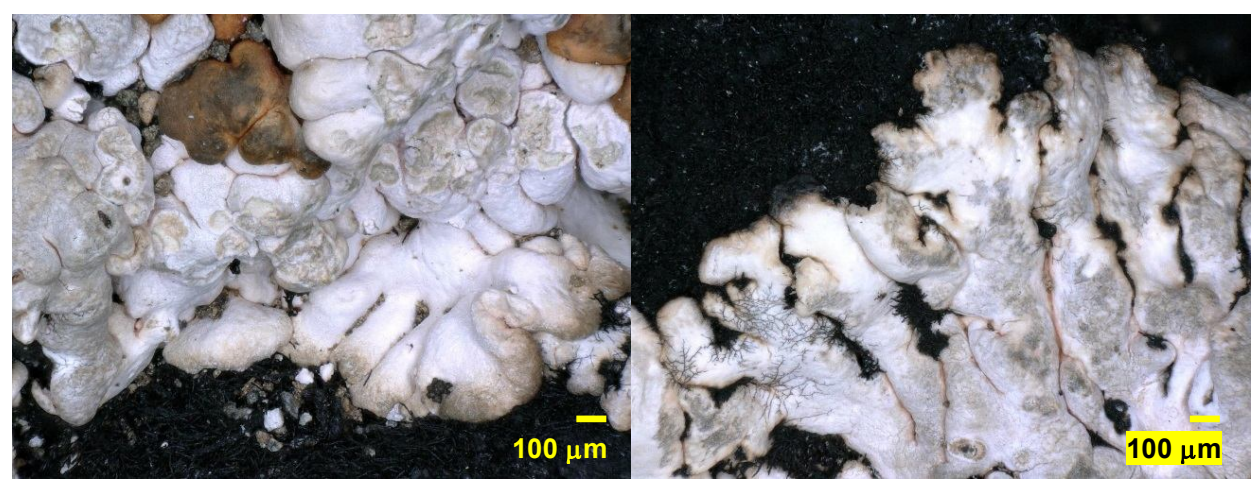

Fig. 9. Detail view on sorediate pits.

Fig. 10. Cover shape of the marginal lobes.

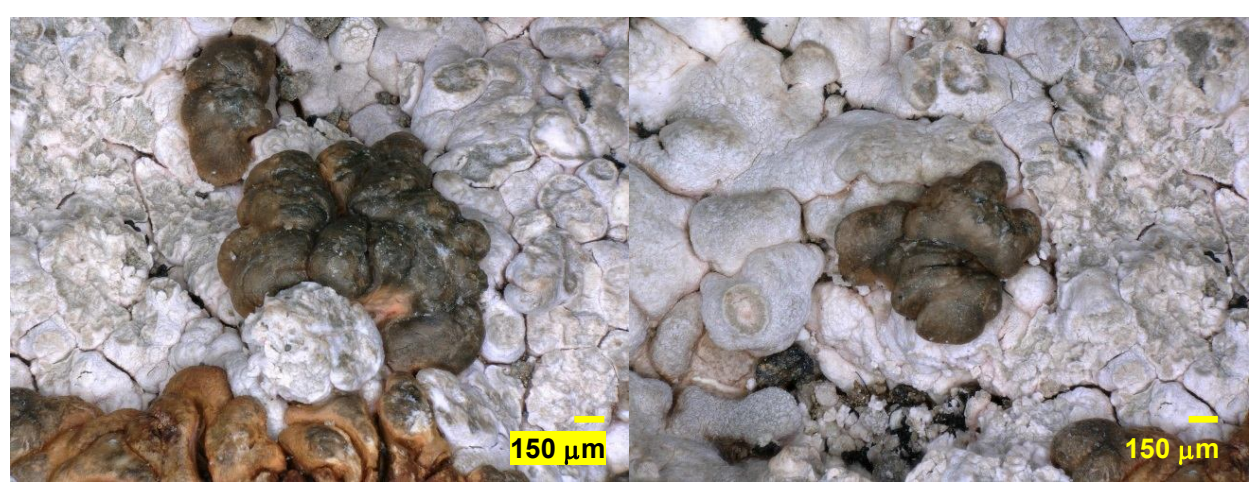

Fig. 11. Small-sized cephalodia.

Fig. 12. Small-sized cephalodium. 


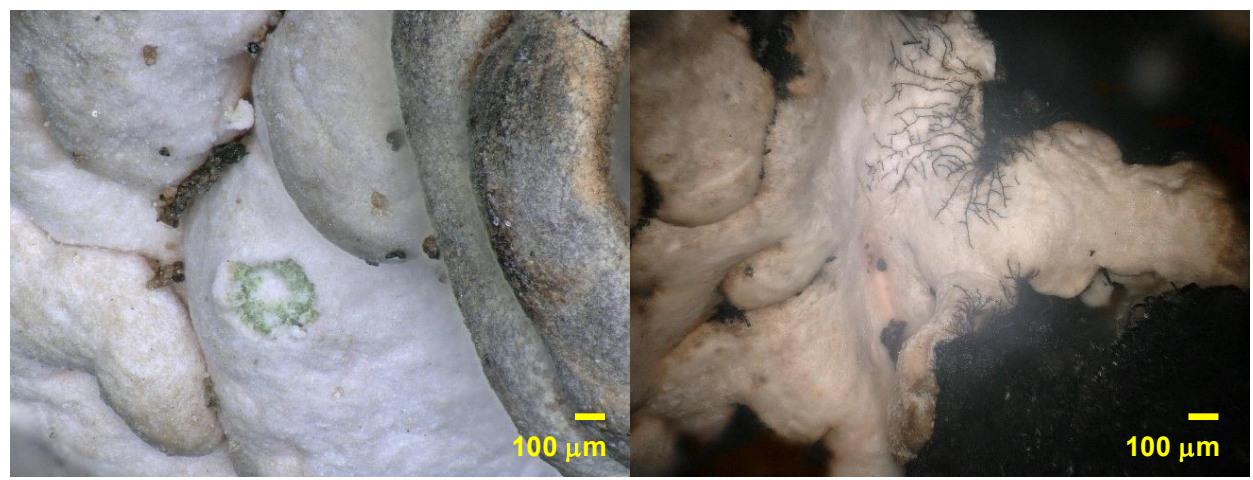

Fig. 13. Early soralium.

Fig. 14. Fungi inviding marginal part of thallus.

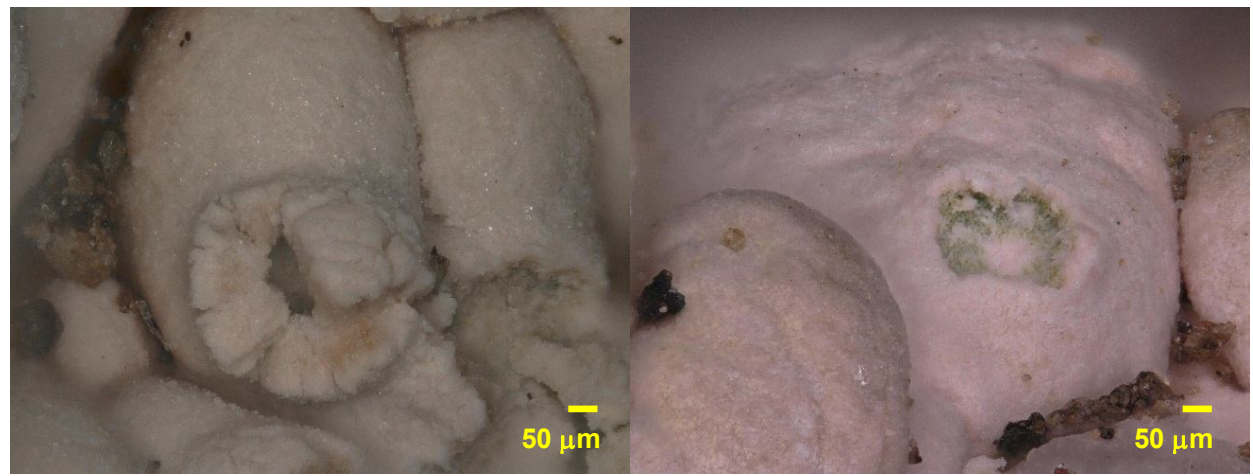

Fig. 15. Globulose soralium.

Sorediate pits are numerous over the upper surface, typically of elliptic shape. The ratio of the length to the width of the sorediate pits reached $1.36 \pm 0.3$. The length of sorediate pits varied from 233 to $652 \mu \mathrm{m}$, reaching mean value of $439.4 \mu \mathrm{m}$ (see Fig. 17). Mean width was $323.0 \mu \mathrm{m}$.

Central cephalodium was of orange colour and had numerous deep cracks in dry state. The shape of central cephalodium was found elliptic (length/width was 2.424/ $1.720 \mathrm{~mm}$ ). Small-sized cephalodia situated outside the central one had orange to olive green colour and elliptic shape as well. Mean length/width of the cephalodia reached $1034 / 611 \mu \mathrm{m}$.
The biometrical parameters found in our study were in accordance to the data reported for $P$. antarctica by Galloway et al. (2005). However, further morphological investigations and detailed analysis of biometrical parameters of $P$. antarctica thalli are recommended in follow-up studies. It is because of the fact that $P$. antarctica and $P$. contortuplicata were shown to be clearly separable by both morphological and molecular means (Beck et al. 2019) but still the two species are relatively similar. This may lead to difficulties in determination of the two species in field studies. 


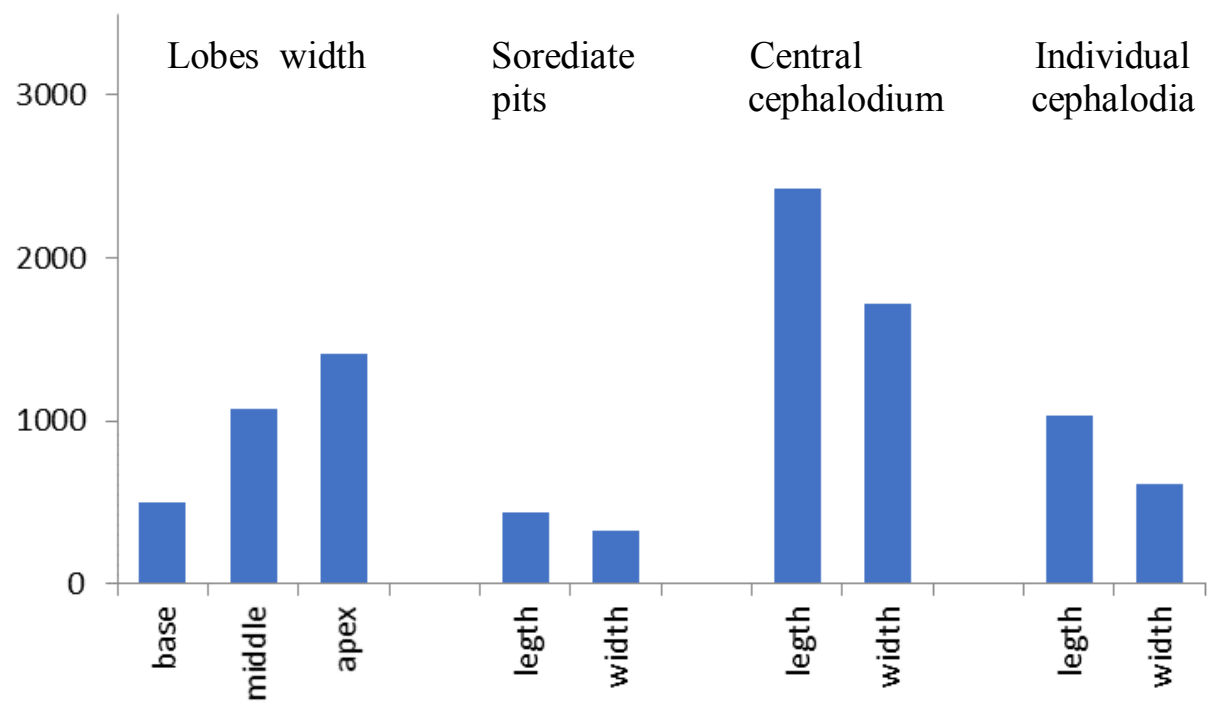

Fig. 17. Biometrical parameters of $P$. antarctica from King George Island. Mean values (in $\mu \mathrm{m}$, calculated for 20-70 replicates for particular parameter) are presented with standard deviation ranging $28-48 \%$ of the means - not shown here).

\section{References}

Beck, A., Bechteler, J., Casanova-Katny, A. and Dzhilyanova, I. (2019): The pioneer lichen Placopsis in maritime Antarctica: Genetic diversity of their mycobionts and green algal symbionts, and their correlation with deglaciation time. Symbiosis, 79:1-24.

CASANOVA-KATNY, A., BARTÁK, M. and GutierRez, C. (2019a): Open top chamber microclimate may limit photosynthetic processes in Antarctic lichen: Case study from King George Island, Antarctica. Czech Polar Reports, 9(1): 61-77.

CASANOVA-KATNY, A., BARTÁK, M. (2019b): One-year passive warming effect on antarctic lichens Placopsis antarctica. In: P. Matos (ed.): Book of Abstracts, XXII Symposium of Cryptogamic Botany. Symposium, Lisboa, Portugal, 2019, pp. 61. http://criptogamica2019.rd.ciencias.ulisboa. pt/PDF/book_of_abstracts.pdf

Colesie, C., Büdel, B., Hurry V. and Green T. G. A. (2018): Can Antarctic lichens acclimatize to changes in temperature? Global Change Biology, 24: 1123-1135.

de los Ríos, A., Raggio, J., Pérez-Ortega, S., Vivas, M., Pintado, A., Green, T. G. A., Ascaso, C. and SANCHO, L. G. (2011): Anatomical, morphological and ecophysiological strategies in Placopsis pycnotheca (lichenized fungi, Ascomycota) allowing rapid colonization of recently deglaciated soils. Flora - Morphology, Distribution, Functional Ecology of Plants, 206: 857864.

Galloway, D. J. (2002): Taxonomic notes on the lichen genus Placopsis (Agyriaceae: Ascomycota) in southern South America, with a key to species. Mitteilungen aus dem Institut für Allgemeine Botanik Hamburg, 30-32: 79-107.

Galloway, D. J., Lewis-Smith, R. - I. and Quilhot, W. (2005): A new species of Placopsis (Agyriaceae: Ascomycota) from Antarctica. The Lichenologist, 37(4): 321-327. 
Galloway, D.J. (2010): Additions to the Placopsis mycobiota (Trapeliaceae, Ascomycota) of southern South America, with notes on new records (including Aspiciliopsis macrophthalma), and a revised regional key to the species. The Lichenologist, 42(6): 727-737.

Galloway, D. J. (2013): The lichen genera Aspiciliopsis, and Placopsis (Trapeliales: Trapeliaceae: Ascomycota) in New Zealand. Phytotaxa, 120(1): 1-194.

Kim, J. H., AhN, I.-Y., Hong, S. G., ANDreev, M., Lim, K.-M., OH, M. J., KoH, Y. J. and HuR, J.-S. (2006): Lichen flora around the Korean Antarctic Scientific Station, King George Island, Antarctic. Journal of Microbiology, 44(5): 480-491.

Lamb, I. M. (1947): A monograph of the lichen genus Placopsis Nyl. Lilloa, 13: 151-288.

Øvstedal, D. O., Lewis Smith, R. I. (2011): Four additional lichens from the Antarctic and South Georgia, including a new Leciophysma species. Folia Cryptogamica Estonica, 48: 65-68.

Palmqvist, K., Dahlman, L., Valladares, F., Tehler, A., Sancho, L. G. and Mattsson, J. E. (2002): $\mathrm{CO}_{2}$ exchange and thallus nitrogen across 75 contrasting lichen associations from different climate zones. Oecologia, 133(3): 295-306.

Pröschold, T., DARIEnKo, T. (2020): The green puzzle Stichococcus (Trebouxiophyceae, Chlorophyta): New generic and species concept among this widely distributed genus. Phytotaxa, 441(2): 113-142. doi:http://dx.doi.org/10.11646/phytotaxa.441.2.2

RAI, A. N. (1990): Cyanobacterial-fungal symbioses: the cyanolichens In: A. N. Rai (ed.): CRC Handbook of Symbiotic Cyanobacteria. CRC Press, Boca Raton, Florida. pp. 9-41.

RAi, A. N., SöDerbäck, E. and Bergman, B. (2000): Cyanobacterium-plant symbioses. New Phytologist, 147: 449-481.

Raggio J., Green T. G. A., Crittenden P. D., Pintado A., Vivas M., Pérez-Ortega S., De los Ríos A. and Sancho L. G. (2012): Comparative ecophysiology of three Placopsis species, pioneer lichens in recently exposed Chilean glacial forelands. Symbiosis, 56: 55-66.

Sancho, L. G., Palacios, D., Green T. G. A., Vivas, M. and Pintado, A. (2011): Extreme high lichen growth rates detected in recently deglaciated areas in Tierra del Fuego. Polar Biology, 34: 813-822.

Schmitt, I., Lumbsch, H. T. and Søchting, U. (2003): Phylogeny of the lichen genus Placopsis and its allies based on Bayesian analyses of nuclear and mitochondrial sequences. Mycologia, 95(5): 827-835.

Schneider, K., Resl, P. and Spribille, T. (2016): Escape from the cryptic species trap: lichen evolution on both sides of a cyanobacterial acquisition event. Molecular Ecology, 25(14): 3453-3468.

Schroeter, B. (1994): In situ photosynthetic differentiation of the green algal and the cyanobacterial photobiont in the crustose lichen Placopsis contortuplicata. Oecologia, 98(2): 212-220.

StrZalka, K., Szymanska, R. and Suwalsky, M. (2011): Prenyllipids and pigments content in selected antarctic lichens and mosses. Journal of the Chilean Chemical Society, 56: 808-811.

Wirtz, N., Lumbsch, H.T., Green, T.G.A., TÜrk, R., Pintado, A., Sancho, L. and Schroeter, B. (2003): Lichen fungi have low cyanobiont selectivity in maritime Antarctica. New Phytologist, 160: 177-183. https://doi.org/10.1046/j.1469-8137.2003.00859.x

\section{Web sources / Other sources}

[1] Australian Antarctic Data Centre (https://data.aad.gov.au/) 